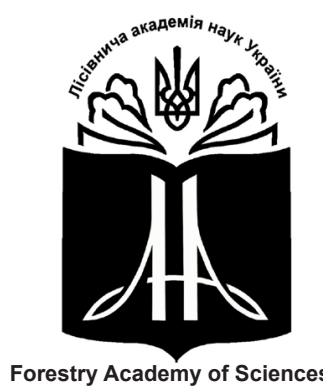

of Ukraine

Наукові праці Лісівничої академії наук України

Proceedings of the Forestry Academy of Sciences of Ukraine

http://fasu.nltu.edu.ua https://doi.org/10.15421/411808

Article received 2018.02.25

Article accepted 2018.05.31
ISSN 1991-606X print

ISSN 2616-5015 online

@ $\triangle$ Correspondence author

Anatoliy Stadnik

stadnikap@ukr.net

Soborna Square, 8/1, Bila Tserkva, 09117, Ukraine

УДК 631.95: 630.26

\title{
Оптимізація структури захисних лісових насаджень та їх систем в агроландшафтах України
}

\author{
А.П. Стадник
}

Розглянуто категорії і системи захисних лісових насаджень у лісомеліоративних районах Украӥни, головні деревні породи для створення ефективних захисних лісових насаджень та особливості їх росту і розвитку. Обтрунтовано шляхи створення оптимізованих систем захисних лісових насаджень, природоохоронні та екологічні пріоритети в агролісових екосистемах. У конщептуальному плані оптимізована система захисних лісових насаджень різного иільового призначення має трунтуватися на ландшафтно-екологічних основах $і$ забезпечувати формування стійкого агролісового ландшафту, в якому стабілізуватиметься екологічний стан, збережеться природно-ресурсний потенціал території, створяться оптимальні умови для росту, розвитку і продуктивності сільськогосподарських культур.

Запропоновано типологічний підхід до створення оптимізованих систем полезахисних лісових насаджень $i$ раціональне використання фіторізноманіття деревних та кущових порід, рекомендовано асортимент деревних рослин, а також типи лісових культур для різних лісорослинних умов. Встановлено оптимальне співвідношення захисних лісових насаджень та інших категорій земель в агроландшафтах Бузько-Дніпровського лісомеліоративного району. Результати проведених досліджень можуть бути використані для створення оптимізованих захисних лісових насаджень різного иільового призначення. Збільшення полезахисної лісистості дасть можливість формувати та покращити начіональну екологічну мережу Украйни, сприяти відтворенню природних екосистем та охороні агроландшафтів, успішному соиіально-економічному розвитку держави. Крім того, зменшаться загрози деградаиії земель, створяться сприятливі умови для ведення сільського господарства.

Ключові слова: степова та лісостепова лісомеліоративні області; категорії і системи; деревні породи; типи лісорослинних умов; асортимент деревних рослин.

Вступ. Захисні лісові насадження (ЗЛН) є основним компонентом агро- і лісоаграрних ландшафтів, тому для забезпечення їх екологічної стабілізації, створення оптимальних умов функціонування сільськогосподарського виробництва першочерговим завданням є розробка ландшафтно-екологічних основ оптимізації систем ЗЛН (Stadnik, 2000, 2004). Такий підхід сприятиме збалансованому використанню, збереженню та відтворенню ландшафтів, упровадженню положень Свропейської ландшафтної конвенції (2000р.).
Системи полезахисних лісових насаджень позитивніше впливають на екологічний і природоохоронний стан в агроекосистемах, ніж окремо створені лісові смуги. Лісові меліорації у системі агроландшафтів сприяють покращенню екологічних, агролісомеліоративних та природоохоронних умов і забезпечують стійке функціонування аграрного виробництва. Однак лісомеліоративна інфраструктура ЗЛН, яка склалася в Україні, є недостатньо ефективною. Щорічні еколого-економічні збитки внаслідок ерозії грунтів перевищують 9 млрд грн.

Стадник Анатолій Петрович - дійсний член Лісівничої академії наук України, доктор сільськогосподарських наук, професор, старший науковий співробітник. завідувач кафедри лісівництва, ботаніки і фізіології рослин. Білоцерківський національний аграрний університет, площа Соборна, 8/1, м. Біла Церква, 09117, Україна. Тел.: + 38-093-900-44-91, 8-(4563)-3-11-50. E-mail: stadnikap@ukr.net 
Свідченням цього є також низька продуктивність сільськогосподарських культур у несприятливі за кліматичними умовами роки. Це є результатом поєднання інтенсивного і екстенсивного господарювання, якому також сприяє велика розораність сільськогосподарських угідь (в окремих областях до $90 \%$ ). Тому поки не буде сформовано стабільної лісомеліоративної інфраструктури, країна систематично матиме значні збитки в галузі сільськогосподарського виробництва, які позначаться на переробній і харчовій промисловості, добробуті громадян (Furdychko \& Stadnik, 2008).

Актуальність питання постає і в тому напрямку, що період створення ЗЛН у розрізі їх видових категорій за окремими землекористувачами вже не забезпечує подальших перспектив самого лісорозведення, відповідного вирішення співвідношень захисних лісів і насаджень. Інтенсифікація сільськогосподарського виробництва суттєво змінила структуру земельного фонду, збільшила розораність, питому вагу ріллі, що спричинило інтенсивні процеси вітрової та водної ерозії. В таких умовах суттєво зростає роль ЗЛН різного цільового призначення та їх систем, як основного стабілізуючого чинника в агролісових екосистемах. У зв'язку з цим, питання оптимізації систем ЗЛН як особливо дієвого середовищеперетворюваного чинника $\epsilon$ особливо актуальним на часі і потребує комплексної оцінки в зональному розрізі, враховуючи їх цільове призначення, просторову орієнтацію, розміщення, оптимальний склад 3 урахуванням типологічних характеристик, конструктивні параметри та інші лісомеліоративні характеристики.

На сьогодні необхідним $є$ створення повних систем захисних лісів і лісонасаджень для різних територій шляхом об'єднання в єдине ціле захисних частин природних лісів, усіх створених захисних лісонасаджень, а також земель, які підлягають залісенню. Нині основною умовою підвищення ефективності сільськогосподарського виробництва $€$ стабілізація компонентів агроекосистем шляхом досягнення оптимального їх співвідношення, завдяки якому буде забезпечене їх стійке функціонування, а також одержання найвищої продуктивності. У концептуальному плані оптимізована система захисних лісових насаджень різного цільового призначення має грунтуватися на ландшафтноекологічних основах і забезпечувати формування стійкого агролісового ландшафту, в якому стабілізуватиметься екологічний стан, збережеться природно-ресурсний потенціал території, створяться оптимальні умови для росту, розвитку і продуктивності сільськогосподарських культур. Збільшення полезахисної лісистості дасть можливість формувати та покращити національну екологічну мережу України, сприяти відтворенню природних екосистем та охороні агроландшафтів, успішному соціально-економічному розвитку держави. Крім того, зменшаться загрози деградації земель, створяться сприятливі умови для ведення сільського господарства.
Об'скти, методологія і методика дослідження. Дослідження проведено в господарствах Київської, Черкаської, Сумської, Херсонської, Вінницької, Миколаївської, Харьківської, Кіровоградської, Львівської, Івано-Франківської, Тернопільської областей та АР Крим.

Об'єкти дослідження - динаміка агроландшафтів України, полезахисних і захисних лісових насаджень різного цільового призначення та їхніх систем. Предмет дослідження - стан і структура земельного фонду, полезахисних і захисних лісових насаджень різного цільового призначення та їхніх систем під впливом екологічних чинників.

Мета дослідження полягає в розробці концептуальних засад створення оптимізованих систем захисних лісових насаджень в агроландшафтах; що сприятиме збільшенню полезахисної лісистості сільськогосподарських територій та підвищенню екологічної ролі захисних лісових насаджень різного цільового призначення.

Методологія дослідження базується на системному і комплексному підходах з вивчення ЗЛН та їхніх систем як багатофункціональних простороцільових форм в агроландшафтах. 3 цією метою розроблено комплексну методику, особливістю якої $€$ ландшафтно-екологічний підхід до вивчення проблеми оптимізації систем ЗЛН в агроландшафтах, антропогенного впливу на функціонування і стійкість агроландшафтів, на перетворювальний вплив агролісомеліорації на антропогенні ландшафти, їх стабілізацію, фіторізноманіття деревних та кущових порід, продуктивність сільськогосподарських культур тощо.

Основні методи дослідження - польовий (натурний), камеральний. Обгрунтовано асортимент деревних та кущових порід для ЗЛН на ландшафтнотипологічній основі у розрізі природних зон України. Відібрано ключові об'єкти досліджень для створення оптимізованих систем захисних лісових насаджень у розрізі природних зон України. Детальні дослідження стану, росту, взаємодії деревних і кущових порід у ЗЛН різного цільового призначення та їх ефективності в агро- та сформованих ними лісомеліоративних системах здійснювали за загальноприйнятими в агролісомеліорації, лісовій таксації апробованими методиками, розробленими УкрНДІЛГА (Methodical recommendations..., 1986), ВНІАЛМІ (Methods of studying..., 1968, Methodological guidelines..., 1981, Methodology of system..., 1985). Математично-статистичну обробку даних проводили з використанням методів кореляційного та регресійного аналізів. Оцінку ефективності функціонування системи заходів, спрямованих на стабілізацію екосистем, здійснювали за загальноприйнятими еколого-економічними методами та методом системного аналізу.

Результати та обговорення. В Україні площа полезахисних лісових смуг становить 442 тис. га, а полезахисна лісистість - 1,3\%. Площа інших захисних лісових насаджень становить 212 тис. га, площа під чагарниковою рослинністю - 303 тис. га. 
Полезахисна лісистість у зоні Степу становить $2,2 \%$, у Лісостепі - 1,0, в Поліссі - 0,44\%. Екологічний стан агроландшафту прийнято оцінювати за співвідношенням орних земель, природних кормових угідь і лісів - для України воно повинно становити 1:1,6:3,6 відповідно. Проте наразі це співвідношення становить 1:0,23:0,3, що свідчить про сильно погіршений екологічний стан агроландшафтів України, у Поліссі - він середньо погіршений, у Лісостепу - сильно погіршений із наближенням до катастрофічного, у Степу - катастрофічний (Sozinov, Kozlov, \& Serdyuk, 1998). Отже, площа ЗЛН різного цільового призначення, а також площа лісів, які виконують захисні функції, $\epsilon$ незадовільною для стабілізації довкілля і створення умов для нормального господарювання.

Аналіз обсягів створення полезахисних і захисних лісонасаджень у країні свідчить, що площа створених полезахисних лісових насаджень (ПЗЛН) 3 кожним роком зменшується. Дослідження, проведені в Бузько-Дніпровському лісомеліоративному районі засвідчили, що полезахисна лісистість регіону становить від 1,8\% - на території Кіровоградської обл. до 2,1-2,2\% - на території Дніпропетровської і Миколаївської областей. Так, у 1991 р. вона становила 3,2 тис. га, в 1995 р. - 1,9, а в 1996 р. 1,3 тис. га, тобто зменшилася у 2,5 раза. Створення ЗЛН у регіоні досліджень фактично виконувалось відповідно до запроектованих обсягів, за винятком Миколаївської обл., де за період 1986-1996 pp. ї було створено лише 3,56 тис. га (майже у 3 рази менше). Отже, полезахисна і загальна лісистість Бузько-Дніпровського лісомеліоративного району $є$ недостатньо задовільною, щоб забезпечити екологічну стабільність довкілля. Обсяги створення лісових насаджень також $€$ мінімальними, i особливо негативним $\epsilon$ те, що спостерігається стійка тенденція до їх зменшення. Полезахисна лісистість повинна бути збільшена не менше ніж у 2-3 рази.

Основна функція ЗЛН у Південному Степу захист грунтів від вітрової ерозії. В основному, вони представлені полезахисними лісовими смугами. Лише незначна частина насаджень $\epsilon$ яружнобалковими та яружними, і розміщені вони на обох (переважно західних) берегах Каховського водосховища. Меліоративний вплив проявляють також придорожні, приканальні та рекреаційні насадження, але через незначну їхню площу та низькі захисні характеристики деревостанів цей вплив $€$ незначним.

Існуючі показники загальної лісистості, полезахисної лісистості в країні (Instrukction..., 1979, Pilipenko, Yukhnovskiy, \& Vedmid, 2004) свідчать про те, що вони значно нижчі від встановлених нормативів. Тому держава робить перші кроки до збільшення обсягів створення ЗЛН різного цільового призначення. Так, згідно з прийнятою постановою Кабінету Міністрів України №189 від 28.02.2011р. (Priority measures..., 2001), планувалося створити в країні 299,5 тис. га ЗЛН. Площа неугідь, на яких можливе створення протиерозійних ЗЛН, становить 1,03 млн га. Першочерговими заходами у 2001-2015 pр. було заплановано створення 299,5 тис. га ЗЛН. Потреба у створенні лісових смуг становить 297,8 тис. га, в т.ч. полезахисних і стокорегулювальних - 155,8 і на берегах річок - 142 тис. га. Загальний обсяг створення лісових смуг по берегах річок на період 20012015 pр. становив 59,8 тис. га, тобто лише $42 \%$ від потреби. Обсяги створення полезахисних і стокорегулювальних лісових смуг на період 2001-2015 pр. становили лише $22 \%$ від потреби. Найбільші обсяги їх створення було заплановано у Миколаївській та Одеській областях - по 3,5 тис. га та у Вінницькій обл. - 3,6 тис. га. Не було заплановано створення таких насаджень у Хмельницькій, Чернігівській та Кіровоградській областях.

Для формування ефективно діючих ЗЛН велике значення має рівень агротехніки їх створення, забезпечення сприятливих умов для їх росту, підтримання необхідної структури лісівничих заходів, охорона, а також боротьба зі шкідниками і пожежами. У практиці лісових меліорацій ці вимоги часто не враховуються, що спричиняе зниження меліоративних характеристик і ефективності ЗЛН. Оптимальна структура полезахисних лісових насаджень за породним складом має вагоме значення для підвищення ефективності полезахисного лісорозведення у різних регіонах України.

Основним критерієм установлення відстані між полезахисними лісовими смугами $є$ захисна висота насаджень, на яку здійснюється розрахунок під час їх створення і яка може бути досягнута за додержання вимог щодо добору порід і технології створення таких насаджень. Оптимальною відстанню між поздовжніми полезахисними лісовими смугами (ПЛЗС) прийнято 35-разову розрахункову висоту дерев. Відстані між поперечними смугами не повинні перевищувати 2000 м, а на піщаних i супіщаних грунтах, що зазнали дефляції, - 1000 м (Guidance on the design..., 1973, Instruction..., 1979). Оптимальне розміщення ЗЛН на місцевості, розширення асортименту використовуваних порід, повний облік агентів, які чинять на них депресійний вплив, удосконалення технологій їх вирощування i лісівничого догляду може забезпечити найвищий екологічний ефект.

Створення полезахисних і стокорегулювальних лісових смуг на водозборах $\epsilon$ визначальним для збалансованого функціонування агроландшафтів. Наразі їх рівень в Україні не відповідає потребам всього $22 \%$. Це віддаляє створення функціонально завершених систем ЗЛН.

Найпредставленішими у досліджуваних регіонах категоріями $€$ полезахисні, стокорегулювальні, прибалкові і прияружні лісові смуги. Полезахисні лісові смуги створюють чистими та мішаними. Стокорегулювальні, прибалкові, прияружні та інші протиерозійні насадження створюють мішаними, 3 декількох деревних порід та кущів. Ширина міжрядь у Степу на звичайних чорноземах та у Лісостепу становить 2,5-3 м. Лісові смуги створюють 3-4-рядними, але не більше 5-ти рядів і шириною не більше 15 м (з урахуванням країв поля). ПЗЛС ство- 
рюють на плоских вододільних і пологих схилах до $2^{\circ}$. Основні лісові смуги розміщують упоперек пануючим у певній місцевості суховійним, заметільним вітрам, а допоміжні - перпендикулярно основним. Стокорегулювальні, прибалкові прияружні лісові смуги створюють упоперек схилів стрімкістю понад $2^{\circ}$. Стокорегулювальні лісові смуги розміщують на межах польових та грунтозахисних сівозмін, а за довжини понад 600-800 м і всередині поля - закладають прияружні лісові смуги до меж привододільного і присіткового фондів. Прибалкові смуги створюють біля бровок еродованих балок, а прияружні - поблизу великих яруг, не ближче 3-5 м від бровки яруги. Прибалкові і прияружні лісові смуги проектують шириною 12,3-21 м, а стокорегулювальні (снігорозподільні) - не більше 15 м.

Для Поліської лісомеліоративної підобласті, до якої входять чотири (№ 1-4) лісомеліоративні райони (Stadnik., 2004), найнеобхіднішими є створення ПЗЛС на орних не зрошуваних землях, які найсильніше зазнають впливу вітрової ерозії. Серед них, полезахисні вітрорегулювальні лісові смуги, алейні і однорядні посадки вздовж доріг на землях сільських господарств, насадження навкруги польових станів, фермерських господарств та населених пунктів, куртинні насадження біля водних джерел, потоконаправлювані лісові смуги, лісові насадження вздовж малих річок, смугові, кулісні, куртинні, кормові лісові насадження. Потрібно досягти широкого впровадження полезахисних стокорегулювальних, водопоглинальних лісових смуг; лісових смуг на осушуваних і осушених землях; лісових смуг для боротьби із заболочуванням.

Для 2-го, 3-го і 4-го лісомеліоративних районів (Stadnik, 2004), необхідним є створення ЗЛН на землях гідрографічного фонду і пісках, у т.ч. прибалкових і прияружних лісових смуг; міжяружних масивних насаджень на еродованих схилах балок i відкосах ярів; улоговинних насаджень; куртинних лісових насаджень на сильно еродованих землях, що не використовуються у сільському господарстві; кольматуючих насаджень (мулофільтри); донних лісових насаджень; насаджень на конусах виносу; куртинних посадок біля водних джерел; потоконаправляючих лісових смуг; лісових насаджень вздовж малих річок. Із насаджень господарсько-захисного, природоохоронного та рекреаційного призначення на сільськогосподарських угіддях та інших землях потрібне створення привитокових лісових, хвилеломних, схилових берегових лісових насаджень; ЗЛН на заболочуваних землях; лісових насаджень вздовж автомобільних доріг; озеленювальних, декоративних та оздоровчих лісових насаджень; рекреаційних лісових насаджень; лісових насаджень навкруги джерел (водозаборів) питної води.

Для лісостепової лісомеліоративної області (Stadnik, 2004), (лісомеліоративні райони №5-13), використовують фактично всі категорії ЗЛН, за винятком лісових смуг на осушуваних та осушених землях. Поряд із тим, у західній лісостеповій лісомеліоративній підобласті категорія полезахисних лі- сових смуг є менш розповсюдженою, а більше значення мають категорії ЗЛН, розташовані на землях гідрографічного фонду і на пісках, оскільки на перший план виходять лісомеліоративні заходи щодо боротьби з проявом водної ерозії. У лісостеповій лісомеліоративній підобласті немає меліоративногосподарських лісових та плодових насаджень на пісках і низки категорій лісомеліоративних насаджень на пасовищах, таких як меліоративно-кормові насадження та деревні зелені зонти, а також лісових посадок на засолених грунтах.

У степовій лісомеліоративній підобласті (лісомеліоративні райони № 14-22), також як і в лісостеповій лісомеліоративній підобласті, застосовуються майже ті самі категорії ЗЛН (Stadnik, 2004). Однак вищевказаний перелік доповнюється лісовими смугами та іншими насадженнями на зрошуваних землях; вітроломними лісовими смугами в садах, виноградниках, ягідниках; лісовими насадженнями на засолених грунтах.

У південно-степовій лісомеліоративній підобласті (лісомеліоративні райони № 23-27), перелік категорій ЗЛН є значно меншим. Переважають агролісомеліоративні насадження, лісомеліоративні посадки на пасовищах. Із насаджень господарськозахисного, природоохоронного та рекреаційного призначення збільшення площ потребують майже всі категорії ЗЛН. Істотно збільшується роль створюваних насаджень на засолених грунтах.

Нами запропоновано класифікацію ЗЛН для агроландшафтів за лісомеліоративними ознаками. За основу взято класифікацію Є.С. Павловського (Pavlovskiy, 1988), але перелік ЗЛН визначено 3 урахуванням специфіки функціонування агроландшафтів України. Потрібно зазначити, що діючою інструкцією (Instruction..., 1979) не передбачено створення пасовищезахисних лісових насаджень. Однак враховуючи, що в Україні існують категорії лук і пасовищ, а в тваринницькій галузі - вівчарство, конярство, птахівництво тощо, такі види насаджень повинні створюватися і позитивно впливати на ефективність сільського господарства. Тому, в запропонованій класифікації ці види ЗЛН враховано.

Полезахисні лісові смуги розміщують на місцевості упоперек напрямку переважаючих вітрів. Рекомендовані нові головні породи - ясен звичайний, береза повисла, клен гостролистий для умов Степу істотно не впливають на зміну міжсмугових відстаней між основними (повздовжніми) смугами. Тому рекомендовані відстані між основними смугами (за умовами систем насаджень) забезпечують захист від несприятливих природних явищ.

Конструктивні характеристики таких смуг грунтуються на рекомендованому асортименті деревних порід. Насадження створюють чистими і мішаними. Крім того, до їх складу варто вводити кущові породи. Для вологодефіцитних районів Степу, які зазнають впливу пилових бур, мають нестійкий сніговий покрив, рекомендують насадження ажурної конструкції. Зважаючи на те, що в регіоні значного поширення набула водна ерозія, у складі насаджень 
повинні бути кущові породи. Подекуди можна практикувати 7- рядні лісові смуги (завширшки не більше 15 м).

Аналіз лісівничо-таксаційних характеристик полезахисних лісових смуг у Лісостепу засвідчив, що рекомендовані головні породи забезпечують ефективний захист сільськогосподарських територій. Насамперед, це насадження за участю дуба звичайного, ясена звичайного, берези повислої, деяких видів тополі тощо.

Оптимізована система ЗЛН різного цільового призначення має забезпечувати формування стійкого агролісового ландшафту, в якому стабілізується екологічна ситуація, створюються оптимальні умови для росту і розвитку сільськогосподарських культур. Система ЗЛН і лісів створюється на основі вже існуючих ЗЛН і лісів, які потрібно охороняти i використовувати, як це прийнято у лісовому господарстві, а також вводити до існуючих ЗЛН і лісів у межах агроландшафтів усю сукупність насаджень, яких не вистачає (Stadnik, 2004, Furdichko \& Stadnik, 2008, 2009). На плато і орних схилах створюють систему полезахисних, вітро- і стокорегулювальних лісових смуг. Гідрографічну сітку доповнює система прибережних, прируслових, балкових, улоговинних, заплавних і терасових ЗЛН. Створення полезахисних і стокорегулювальних лісових смуг на водозборах є визначальним для збалансованого функціонування агроландшафтів.

Під час вирощування полезахисних, водорегулювальних, прибалкових і прияружних лісових смуг необхідно прагнути до створення найбільш ефективних їх конструкцій. Продувні ПЗЛС можна рекомендувати для районів 3 холодною і сніжною зимою, а також для районів із зимовими відлигами. Ажурні лісові смуги краще рекомендувати для сухостепових районів і тих, що страждають від пилових бур, iз нестійким сніговим покривом і місць 3 м’ якою зимою (Instruction..., 1979). ПЗЛС створюють чистими і мішаними Зазвичай до складу ПЗЛС вводять одну головну породу. В окремих випадках для прискорення захисної дії смуг із дуба, сосни та інших дерев 3 повільним ростом в узлісний ряд вводять швидкорослу породу. ПЗЛС із двох-трьох рядів, створюють лише $з$ головної породи. На грунтах каштанового комплексу і південних чорноземах в узлісні ряди можна вводити 20-35\% низькорослих кущів (від загальної кількості садивних місць в узлісному ряду) в чергуванні з деревними породами. Лісові смуги на зрошуваних землях створюють продувної та ажурної конструкцій.

Водорегулювальні, прибалкові, прияружні лісові смуги та інші протиерозійні насадження створюють мішаними із декількох деревних порід і кущів. Конструкція таких насаджень визначається їх функціональними особливостями. У водорегулювальних смугах кущі висаджують у крайньому ряду 3 верхнього боку смуги, в прибалкових і прияружних - в узлісних рядах (в окремих випадках в одному, або двох середніх рядах). У крайні від бровки ряди прияружних смуг висаджують коренепарост- кові породи, а для обнасінення відкосів ярів - клени і робінію. Прибалкові і прияружні лісові смуги 3 боку пасовищ обсаджують колючими кущами.

Прибалкові і прияружні лісові смуги створюють завширшки 12,5-21 м, стокорегулювальні (снігорозподільні) - не більше 15 м. Створення ефективних систем ЗЛН певною мірою залежить від природнокліматичних умов, ландшафтно-типологічної характеристики території, існуючої структури земельного фонду тощо. Як приклад, розглянемо системи ЗЛН, розташовані на території Куяльницької селищної ради Котовського р-ну та Балтської міської ради Балтського р-ну Одеської обл., які входять до складу Лісостепової лісомеліоративної області, Придністровсько-Подільського лісомеліоративного району (Stadnik, 2004 ).

Дослідження якісного стану, лісівничотаксаційних показників полезахисних лісових смуг та їх систем у вищевказаних селищних радах засвідчили, що встановлений асортимент деревних порід, рекомендований для цих умов, значною мірою реалізовано на практиці. Вибрані для детального обстеження системи ЗЛН мають у своєму складі дубові, дубово-ясеневі, кленові, тополеві, березові, акацієві насадження. Зважаючи на те, що останніми роками полезахисні смуги практично не створюють (більша частка припадає на ЗЛН у меліоративному фонді), досліджувані насадження мають переважно середній і старший вік. Значну їхню частину становлять дубові насадження різного складу, які ростуть переважно у типі лісорослинних умов $D_{l}$. Дубові насадження в системі ЗЛН на території Куяльницької селищної ради створено гніздовим способом, у 45-річному віці мають середню висоту 14-16 м, середній діаметр - до 36 см. У підліску переважають клен татарський, бузина чорна, жовта акація. Зімкнутість крон висока - 0,8-0,9. Насадження мають непродувну або ажурно-непродувну конструкцію. Нехтування рубками догляду, густий кущовий ярус спричиняє зниження їхніх захисних властивостей. Нормальний розвиток крон у горизонтальному та вертикальному профілях сприяє формуванню потенційно ефективних насаджень, які за проведення лісівничого догляду повністю відповідатимуть своєму призначенню.

Дубові лісові смуги в господарствах Балтського p-ну представлено мішаними посадками 3 ясеном звичайним, ясеном зеленим, черешнею, кленом татарським. Ростуть вони також переважно в умовах $D_{1}$, досягаючи в 35-40-річному віці середніх висоти і діаметра, відповідно 16 м та 35 см. Початкове їх розташування $-1,5 \times 0,5$ м, кількість рядів - 4-7. Формують вони смуги непродувної та ажурної конструкції. Зімкнутість крон становить 0,8-0,9. Смуги мають підлісок середньої густоти та мертве трав'яне вкриття. Дуб є ефективною породою у лісових смугах, як за показниками росту, так і за формуванням лісового середовища.

Ясеневі ЗЛН представлені як чистими, так і мішаними насадженнями. У 40-45-річному віці у типі лісорослинних умов $D_{2}$ ясен звичайний має висо- 
ту 22 м і середній діаметр 30,4 см. Для забезпечення їхньої стійкості, особливо у типі $D_{l}$, необхідна участь дуба або супутніх порід з щільною кроною кленів і липи.

Кленові, тополеві, акацієві ЗЛН у відповідних типах лісорослинних умов формують ефективні просторово цільові структури.

Вивчення сучасного стану полезахисних лісових смуг проводили в системах, розміщених на полях колишніх господарств ім. акад. Заболотного, «Україна» та «Зоря» Крижопільського р-ну Вінницької обл. у типі лісорослинних умов $D$, на сірих лісових грунтах. Смуги насаджень старшого віку мають більшу кількість рядів - до 6-7, молодшого віку до 5-ти рядів. Це, в основному, насадження дуба звичайного, дуба червоного, ясена звичайного, білої акації, черешні.

Дослідження полезахисних смуг старшого віку за участю дуба звичайного (гніздова посадка) в господарстві «Україна» свідчить, що дуб має задовільні показники росту. Так, у 45-річному віці в умовах $D$ висота його досягає 13,5 м, середній діаметр 33,5 см. Підлісок середньої густоти формують груша лісова, шипшина, клен татарський. Трав'яне вкриття мертве, але на значних ділянках є задерніння. У смугах необхідно проводити рубки догляду.

Дубові насадження створені способом рядового садіння, в основному, з початковим розміщенням $2 \times 0,5$ м, і тільки в молодих посадках деревні рослини розташовані рідше $-3 \times 0,7$ м.

Окрім дуба звичайного, у полезахисних смугах часто трапляється дуб червоний як у чистих, так i мішаних посадках. Чисті насадження з дуба червоного також мають задовільні показники росту, досягаючи у 48-річному віці висоти 18 м та діаметра 18-21 см. Зімкненість намету - 0,8. Дерева дуба червоного мають компактнішу крону і формують смуги ажурної конструкції. У мішаних насадженнях (у складі зазвичай ясен звичайний до п'яти одиниць та черешня) дуб червоний має задовільні показники росту за висотою і діаметром. Так, у 6 -рядній смузі в умовах $D$, за розміщення $2 \times 0,7$ м дуб має висоту 11,8 м і діаметр 14 см. Зімкненість крон - 0,8 , конструкція смуги - ажурна. Очищення стовбура від гілок - на висоту 1-2 м. У насадженні зафіксовано мертве трав'яне вкриття. У старших за віком смугах дуб червоний має висоту близько 17-20 м і діаметр 16,7-21 см.

Черешня у складі ЗЛН позитивно впливає на їх конструктивні характеристики (ущільнює профіль). Задовільні характеристики мають насадження ясена звичайного із дубом червоним за однакової їхньої частки у складі насаджень не тільки у старшому, але й у молодшому віці. Так, у 12-річному віці дуб і ясен мають висоту близько 6 м і діаметр $-8,5$ см. Зімкненість крон - 0,8 (за початкового розміщення дерев $3 \times 0,7$ м). Насадження формують непродувну та ажурну конструкції. У насадженнях необхідно провести рубки догляду.

Обстеження білоакацієвих насаджень засвідчило, що навіть у типі $D_{2}$ акація біла 3 віком втрачає свої лісівничо-меліоративні характеристики. За двометрової ширини міжрядь спостерігається відпад, суховершинність, на прогалинах з'являється злакова рослинність. Як і в степових умовах (звичайні чорноземи), введення акації до полезахисних смуг $\epsilon$ недоцільним, окрім протиерозійних посадок. Черешню доцільно вводити чистими посадками (алеями) в умовах $D_{2}$ або у змішуванні з ефективнішими деревними породами - дубом, ясенем, березою.

Дослідження стану і ефективності ПЗЛС здійснені у типовій для Задонецько-Донської північностепової лісомеліоративної підобласті (Старобільський лісомеліоративний район) системі ПЗЛС (господарство «Дружба» Борівського р-ну Харківської обл., полезахисна лісистість - 1,3\%). На території господарства створено 44,5 га полезахисних лісосмуг завдовжки 43 км. Основними лісотвірними породами в лісосмугах $є$ дуб звичайний, ясен звичайний, деякі види тополь та в'язів. У комплексі 3 іншими категоріями захисних лісових насаджень $\mathrm{i}$ агротехнічними заходами вони забезпечують сприятливі умови для доброго розвитку, збереженості і підвищення врожайності сільськогосподарських культур.

Оптимальна структура полезахисних лісових насаджень (ПЗЛН) за породним складом має вагоме значення для підвищення ефективності полезахисного лісорозведення у різних регіонах України. Питома вага дуба звичайного в структурі ПЗЛН Бузько-Дніпровського лісомеліоративного району становить 35\% (Stadnik, 2004). Близько 60\% припадає на недостатньо ефективні ПЗЛН - із робінії псевдоакації та гледичії (34\%), ясена звичайного і клена ясенелистого (21\%), в'язових (2\%). Узагальнення досвіду вирощування полезахисних лісових смуг на звичайних чорноземах свідчить, що найкращими лісівничо-біологічними властивостями характеризуються дуб звичайний, тому в цьому регіоні він повинен ширше використовуватися для створення полезахисних насаджень. У 40-річному віці в типі $D_{l}$ він має висоту $12-13$ м. На відміну від чистих за складом ясеневих насаджень, у мішаних смугах ясен звичайний характеризується кращими показниками росту. Найсприятливіші екологічні умови для нього створюються у складі таких щільнокронних порід, як клен польовий і дуб звичайний. Ясен у таких насадженнях не поступається в рості дубу.

Мішані ясеневі лісові смуги за участю акації білої, клена ясенелистого, гледичії триколючкової, в'яза граболистого за якісним станом і ростом займають проміжне місце. У всіх досліджуваних смугах 3 ясенем звичайним спостерігається позитивний вплив кущів на їх ріст. У таких насадженнях ясен у 30-40-річному віці має висоту 14-16 м. Вид можна вводити у полезахисні лісові насадження як головну породу, проте його частка не повинна перевищувати 30-40\%. Створювати мішані лісові смуги $з$ ясена звичайного, дуба звичайного та клена гостролистого доцільно в типах $D_{1-2}\left(\mathrm{C} \Gamma_{1-2}\right)$ та $D_{2}\left(\mathrm{C}_{2}\right)$. Вводити акацію білу як головну породу в полезахисні лісові смуги недоцільно внаслідок іiі 
низької екологічної стійкості і відносно незначної меліоративної ефективності. Наразі акацієві смуги потребують реконструкції.

Вивчення стану і динаміки росту лісових смуг 3 берези повислої свідчить, що ця порода має задовільні показники росту, досягаючи у 25-річному віці у типі $D_{1}\left(\mathrm{C \Gamma}_{1}\right)$ висоти $12-17$ м, тоді як дуб звичайний має таку висоту в 40-50 років. Максимальний поточний приріст берези за висотою спостерігався у 5-10-річному віці, у крайніх рядах - 0,8 м, у середніх - 1,2 м. Зниження його з віком пояснюється, насамперед, загущенням насаджень та низькою вологістю грунту. Березу повислу також рекомендовано використовувати для створення смуг у вказаному районі.

Задовільними показниками росту в чистих i мішаних насадженнях у лісорослинних умовах $D_{1}\left(\mathrm{C \Gamma}_{1}\right)$ характеризується клен гостролистий. У 25-річному віці він має висоту 11-12 м, середній приріст за висотою - 0,5 м. Максимальний поточний приріст за висотою спостережено у перші 5-10 років (0,6 м). У чистих за складом насадженнях він забезпечує створення стійких високорослих деревостанів. Це дає змогу використовувати породу не лише як супутню, але й як головну.

У полезахисних лісових смугах добре себе зарекомендувала черешня. В умовах $D_{l}\left(\mathrm{C} \Gamma_{1}\right)$ у 20-річному віці вона досягає висоти 10-11 м і поточного приросту близько 0,7 м. Формує компактну крону, характеризується ефективним очищенням від гілок. За розміщення у крайніх рядах дубових лісових смуг черешня обмежує ріст крони дуба з боку поля і сприяє формуванню продувної конструкції природним шляхом. Ї̈̈ можна рекомендувати як супутню породу для дуба і берези із подеревним змішуванням або змішуванням чистими рядами 3 розміщенням у ряду через 1,0-1,5 м. У дубових насадженнях іiі доцільно вводити у крайні ряди за ширини міжрядь не менше 2,5 м. Ефективність полезахисного лісорозведення значною мірою залежить від оптимального складу насаджень.

Багаторічні дослідження підтвердили, що дуб звичайний, береза повисла, ясен звичайний, клен гостролистий за своїми лісівничо-біологічними показниками є породами найефективнішими для ПЗЛН, і тому повинні отримати широке впровадження у практику полезахисного лісорозведення. При цьому частка дуба у складі насаджень, як головної породи в лісових смугах, повинна становити не менше $60 \%$. Вводити його необхідно у сухіших типах лісорослинних умов $D_{0-1}\left(\mathrm{C}_{0-1}\right), D_{1}\left(\mathrm{C} \Gamma_{1}\right)$. Інші $40 \%$ повинні заповнити полезахисні смуги з берези повислої (15\%), ясена звичайного (15\%) і клена гостролистого (10\%). Полезахисні лісові смуги 3 березою повислою значно раніше починають проявляти захисний вплив на міжсмугові поля, у них раніше наступає період окупності i, порівняно 3 лісовими смугами іншого складу, зокрема із дуба звичайного, вони є ефективнішими. Однак, пропонована значно менша їі частка у структурі лісових смуг пояснюється відсутністю достатньо сприятли- вих умов місцезростання $\left(\mathrm{C}_{1-2}, \mathrm{C} \Gamma_{2}\right)$, в яких береза повисла не в змозі конкурувати 3 дубом звичайним.

Подібні твердження стосуються ПЗЛН 3 клена гостролистого та ясена звичайного, що потребують свіжіших умов зростання $-D_{1-2}\left(\mathrm{C} \Gamma_{1-2}\right)$ та $D_{2}\left(\mathrm{C} \Gamma_{2}\right)$.

Отже, пропонована структура полезахисних лісових смуг за породним складом повинна мати таке співвідношення: 60\% - дуб, 15 - клен, 15 - береза, $10 \%$ - ясен. За такого співвідношення полезахисні лісові насадження зможуть краще використовувати потенційні можливості лісорослинних умов (у 2-2,5 раза), зберігаючи свої агролісомеліоративні характеристики і лісівничо-біологічні властивості, характерні для швидкоростучих і довговічних порід (Furdichko \& Stadnik, 2008, 2009).

Забезпечення повної реалізації біологічного потенціалу створюваних ПЗЛН неможливе без врахування типів лісорослинних умов. Нами запропоновано типологічний підхід до створення оптимізованих систем полезахисних лісових насаджень. У табл. 1 наведено асортимент деревних порід залежно від типів лісорослинних умов у степовій лісомеліоративній області (звичайні чорноземи).

Отже, в умовах степової лісомеліоративної області на звичайних чорноземах можна успішно вводити як головні породи березу повислу, ясен звичайний, клен гостролистий, черешню, на засолених грунтах - ясен гостроплодий, а в умовах лісостепової лісомеліоративної області - дуб червоний (Stadnik , 2004). У табл. 2 наведено асортимент деревних рослин залежно від типів лісорослинних умов у лісостеповій лісомеліоративній області.

У створених нами дослідно-виробничих ПЗЛС у Степу на звичайних чорноземах (господарства Лозівського р-ну Харківської обл.), у 5-рядних дубово-кленових смугах, де береза повисла була введена окремими групами у різних рядах, у 20-річному віці вона досягла висоти 13-14,5 м, а діаметра $-23,0$ см. Введення берези істотно прискорює захисну дію полезахисних смуг. При висоті берези в 14,5 м висота дуба звичайного та клена гостролистого у смузі становлять лише 11,0 та 9,5 м відповідно. Вирощування ЗЛН з добором порід відповідно до типів лісорослинних умов дасть можливість значно зменшити витрати на їх вирощування, істотно підвищити їхні захисні параметри.

Полезахисні лісові смуги у степовій частині Криму представлені переважно насадженнями 20-30-річного віку. Головними породами в них є в'яз дрібнолистий, біла акація, гледичія триколючкова, маслинка вузьколиста, тополя. Для кращого змикання крон у міжряддях вважаємо за доцільне встановлювати ширину міжрядь не більше 3-3,5 м. У створюваних лісових смугах потрібно широко застосовувати змішування у крайніх узлісних рядах деревних порід 3 кущами, у т. ч. такими стійкими для цього району, як скумпія звичайна, вишня магалебська, деякі види свидини і жимолості. На пасовищах і сильно засолених землях потрібно створювати посадки $з$ маслинки вузьколистої й тамариксу галузистого, формуючи їх рубками догляду у вигляді дерев. 


\section{Асортимент деревних рослин залежно від типу лісорослинних умов} у степовій лісомеліоративній області (звичайні чорноземи)

\begin{tabular}{|c|c|}
\hline Деревний вид & $\begin{array}{c}\text { Типи лісорослинних умов (за Є. В. Алексеєвим, } \\
\text { П.С. Погребняком, О. Л. Бельгардом) }\end{array}$ \\
\hline \multicolumn{2}{|l|}{ Головні: } \\
\hline Береза повисла Betula verrucosa $\mathrm{L}$. & $\mathrm{D}_{2}\left(\mathrm{C} \Gamma_{1-2}\right)$ \\
\hline Горіх чорний Juglans nigra L. & $\mathrm{D}_{0}, \mathrm{D}_{1}, \mathrm{D}_{2}\left(\mathrm{C} \Gamma_{0-1}, \mathrm{C} \Gamma, \mathrm{C} \Gamma_{1-2}\right)$ \\
\hline Дуб звичайний Quercus robur L. & $\mathrm{D}_{0}, \mathrm{D}_{1}, \mathrm{D}_{2}\left(\mathrm{C} \Gamma_{0-1}, \mathrm{C} \Gamma, \mathrm{C} \Gamma_{1-2}\right)$ \\
\hline Модрина сибірська Larix sibirica L. & $\mathrm{D}_{1}, \mathrm{D}_{2}\left(\mathrm{C} \Gamma_{1}, \mathrm{C} \Gamma_{1-2}\right)$ \\
\hline Сосна звичайна Pinus silvestris L. & $\mathrm{D}_{0},\left(\mathrm{C} \Gamma_{0-1}\right)$ \\
\hline Клен гостролистий Acer platanoides L. & $\mathrm{D}_{1}, \mathrm{D}_{2}\left(\mathrm{C} \Gamma_{1}, \mathrm{C} \Gamma_{1-2}\right)$ \\
\hline Тополя берлінська Populus berolinensis D. & $\mathrm{D}_{2}\left(\mathrm{C \Gamma}_{1-2}\right)$ \\
\hline Тополя дельтовидна Populus deltoides March. & $\mathrm{D}_{2}\left(\mathrm{C} \Gamma_{1-2}\right)$ \\
\hline Тополя китайська Populus simonii C. & $\mathrm{D}_{2}\left(\mathrm{C} \Gamma_{1-2}\right)$ \\
\hline Тополя (гібридні форми) Populus Moskoviensis & $\mathrm{D}_{2}\left(\mathrm{C} \Gamma_{1-2}\right)$ \\
\hline Ясен звичайний Fraxinus excelsior L. & $\mathrm{D}_{2}\left(\mathrm{C} \Gamma_{1-2}\right)$ \\
\hline \multicolumn{2}{|l|}{ Супутні: } \\
\hline Берека Sorbus torminalis L. & $\mathrm{D}_{2}\left(\mathrm{C} \Gamma_{1-2}\right)$ \\
\hline Горобина звичайна Sorbus aucuparia L. & $\mathrm{D}_{1}\left(\mathrm{C} \Gamma_{1-2}\right)$ \\
\hline Груша звичайна Pyrus communis L. & $\mathrm{D}_{1}\left(\mathrm{C} \Gamma_{1}\right)$ \\
\hline Клен польовий Acer campestre L. & $\mathrm{D}_{1}, \mathrm{D}_{2}\left(\mathrm{C} \Gamma_{1}, \mathrm{C} \Gamma_{1-2}\right)$ \\
\hline Клен гостролистий Acer platanoides L. & $\mathrm{D}_{1}, \mathrm{D}_{2}\left(\mathrm{C} \Gamma_{1}, \mathrm{C} \Gamma_{1-2}\right)$ \\
\hline Липа серцелиста (дрібнолиста) Tilia cordata Mill. & $\mathrm{D}_{1}, \mathrm{D}_{2}\left(\mathrm{C} \Gamma_{1}, \mathrm{C} \Gamma_{1-2}\right)$ \\
\hline Липа широколиста Tilia platyphyllos Scop. & $\mathrm{D}_{2}\left(\mathrm{C} \Gamma_{1-2}\right)$ \\
\hline Черешня (вишня пташина) Cerasus avium L. & $\mathrm{D}_{2}\left(\mathrm{C} \Gamma_{1-2}\right)$ \\
\hline Яблуня лісова Malus silvestris Mill. & $\mathrm{D}_{2}\left(\mathrm{C} \Gamma_{1-2}\right)$ \\
\hline Ясен зелений (ланцентний) Fraxinus viridis Micha. & $\mathrm{D}_{2}\left(\mathrm{C} \Gamma_{1-2}\right)$ \\
\hline
\end{tabular}

\section{Асортимент деревних рослин залежно від типу лісорослинних умов у лісостеповій лісомеліоративній області}

\begin{tabular}{lc}
\hline \multicolumn{1}{c}{ Деревний вид } & Типи лісорослинних умов (за С. В. Алексеєвим, \\
П.С. Погребняком, О. Л. Бельгардом)
\end{tabular}


Клен гостролистий Acer platanoides L.

Клен несправжньоплатановий (явір) Acer pseudoplatanus L.

Липа серцелиста (дрібнолиста) Tilia cordata Mill.

Липа широколиста Tilia platyphyllos Scop.

Черешня (вишня пташина) Cerasus avium L.

Яблуня лісова Malus silvestris Mill.

$$
\begin{gathered}
\mathrm{C}_{2}, \mathrm{C}_{3}, \mathrm{D}_{1-2}, \mathrm{D}_{2}, \mathrm{D}_{3} \\
\mathrm{D}_{1-2}, \mathrm{D}_{2}, \mathrm{D}_{3} \\
\mathrm{D}_{1}, \mathrm{D}_{2} \\
\mathrm{D}_{1}, \mathrm{D}_{2} \\
\mathrm{D}_{2}, \mathrm{D}_{3} \\
\mathrm{D}_{2}, \mathrm{D}_{3}
\end{gathered}
$$

Під час вибору порід потрібно повніше враховувати особливості грунтових умов і віддавати перевагу породам, які, за результатами 30-річного лісокультурного досвіду у даному районі виявилися найстійкішими і довговічними: ясен гостроплодий, в'яз перисто-гілчастий, гледичія триколючкова, софора японська. На менш засолених i кам'янистих грунтах доцільно вводити хвойні породи (сосну кримську, тую східну, яловець звичайний). Доцільно широко практикувати вирощування полезахисних лісових смуг та інших лісових насаджень на зрошуваних землях з введенням різних видів тополі, горіха волоського та інших цінних і швидкорослих порід. Для створення лісових насаджень на засолених землях доцільно використовувати такі деревні породи: біоту східну, сосну кримську, гледичію триколючкову, маслинку вузьколисту; із кущів - бирючину звичайну, жимолость татарську, аморфу чагарникову, свидину кроваво-червону, церцис канадський, тамарикс чотиритичинковий (Plugatar, 2008, Agaponov, Plugatar, Neonetta, \& Shvets, 2007).

Висновки. Аналіз ступеня повноти і завершеності систем ЗЛН на теперішній час і необхідності їх оптимізації свідчить, що полезахисна лісистість в країні складає лише 1,3\%, зокрема, у зоні Степу $-2,2 \%$, у Лісостепу - 1,0 і в Поліссі - лише $0,4 \%$. Отже, площа ЗЛН різного цільового призначення, а також лісів, що виконують захисні функціiі, $є$ недостатньою для того, щоб стабілізувати довкілля і створити умови для нормального господарювання. Показники загальної лісистості, полезахисної лісистості в країні є нижчими від встановлених нормативів.

Сучасний стан ЗЛН та їх систем різного цільового призначення не забезпечує захищеності сільськогосподарських територій та стабільне функціонування агроландшафтів України. Недостатня їхня полезахисна лісистість та захищеність, надмірна розораність, низька частка в структурі сільськогосподарських земель умовно стабільних угідь - сіножаті, пасовища, багаторічні насадження, ЗЛН не забезпечує належної екологічної стійкості агроландшафтів.

Система ЗЛН і лісів формується на основі існуючих ЗЛН і лісів, які потрібно охороняти і використовувати відповідно до положень лісомеліоративного впорядкування, як це прийнято в лісовому господарстві, а також включати до існуючих ЗЛН і лісів у межах агроландшафтів усю сукупність насаджень, яких не вистачає для захисту територій згідно встановлених нормативів. На плато і орних схилах необхідно створити систему полезахисних, вітро- і стокорегулювальних лісових смуг, на елементах гідрографічної сітки - систему прибережних і прируслових, балкових, улоговинних, заплавних і терасових ЗЛН. Існуючі ЗЛН, якщо їх створено 3 певними порушеннями, повинні випрацювати свій агролісомеліоративний ресурс, а нові необхідно створювати 3 урахуванням отриманих результатів досліджень.

Основним критерієм установлення відстані між ПЗЛС є захисна висота насаджень, на яку ведеться розрахунок під час їх створення і яка може бути досягнута за дотримання вимог щодо добору породного складу і технологій створення захисних насаджень. Оптимальною відстанню між поздовжніми ПЗЛС є 35-разова розрахункова висота дерев.

Реалізація запропонованих підходів створення оптимізованих систем ЗЛН різного цільового призначення в агроландшафтах дасть можливість істотно підвищити їх ефективність і сприятиме якіснішому впровадженню державних лісівничих, лісомеліоративних та екологічних програм.

\section{Бібліографічні посилання}

Agaponov, M.N., Plugatar, Yu.V., Neonetta, O. O., Shvets, Yu.P. (2007). The composition of the protective plantings at the Steppe Crimea. Scientific herald of the National Agrarian University: Forestry. Decorative gardening, 113, 200-207 (in Ukrainian).

Encyclopedia of agroforestry (2004). Volgograd: VNIALMI (in Russian).

Furdychko, O.I., Stadnik, A.P. (2008). Forest land reclamations as basic factor of stabilizing of steppeecosytem. Ecology and noosferologiya, 19 (34), 13-24 (in Ukrainian).

Furdychko, O. I., Stadnik, A. P. (2009). Management of agrarian landscapes by forest melioration methods on the basis of balanced development. Agroecological journal, 3, 5-12 (in Ukrainian).

Guidance on the design and cultivation of protective forest plantations on the lands of agricultural enterprises (1973). Moscow: Head (in Russian).

Instruction on the design and cultivation of protective forest plantations on the lands of agricultural enterprises of the Ukrainian SSR (1979). Kyiv: Harvest (in Ukrainian).

Methodological guidelines for conducting a forest amelioration survey of sloping lands (1981). Volgograd: VNIALMI (in Russian).

Methodology of system researches of forest agrarian landscapes (1985). Moskow: VNIALMI (in Russian). 
Methodical recommendations on anti-erosion forest plantations for slope agriculture in the Ukrainian SSR (1986). Kharkiv: Ukrainian Research Institute of Forestry \& Forest Melioration (in Russian).

Methodical recommendations on the design of a complex of anti-erosion measures in the territory of the Ukrainian SSR (1982). Voroshilovgrad: UNIIZPE (in Russian).

Methods of studying the complex of agro-technical and forest-meliorative measures of soil protection from wind erosion (1968). Volgograd: VNIALMI (in Russian).

Pavlovskiy, E.S. (1988). Ecological and social problems of agroforestry. Moskow: Agropromizdat (in Russian).

Pilipenko, O. I., Yukhnovskiy. V. Yu., \& Vedmid M. M. (2004). Systems of soil protection against erosion. Kyiv: Zlatoyar (in Ukrainian).

Plugatar, Yu, V. (2008). From the forests of Crimea. Kharkiv: New word (in Ukrainian).

Priority measures for the creation of protective forest plantations on public lands and river basins: Decision from February, 2011.02.28, №189 (2001). Information from the cabinet of ministers of Ukraine. Retrieved from http://zakon5.rada.gov.ua/laws/ show/189-2001-\%D0\%BF (in Ukrainian)

Sozinov,O.O.,Kozlov.M.V.,\&Serdyuk.A. G.(1998).The modern degradation processes, ekologicalagronomic state and estimation of agricultural lands potential for creation of ecologically clean areas for raw material and economies. Agroekologiya and biotechnology, 2, 54-65 (in Ukrainian).

Stadnik, A.P. (2000). Conceptual bases of forest reclamation development for optimization of natural landscapes in Ukraine. Forestry and Forest Melioration, 102, 10-16 (in Ukrainian).

Stadnik, A.P. (2004). Zoning of Forest Melioration in Ukraine as landscape ecological basis for creation of the national optimized system of the protective forest planting. Forestry and Forest Melioration, 106, 137149 (in Ukrainian).

\section{Оптимизация структуры защитных лесных насаждений и их систем в агроландшафтах Украины}

\section{А.П. Стадник ${ }^{1}$}

Интенсификация сельскохозяйственного производства существенно изменила структуру земельного фонда, увеличила распаханность, удельный

Стадник Анатолий Петрович - действительный член Лесной академии наук Украины, доктор сельскохозяйственных наук, профессор, старший научный сотрудник, заведующий кафедрой лесоводства, ботаники и физиологии растений. Белоцерковский национальный аграрный университет, площадь Соборная, 8/1, г. Белая Церковь, 09117, Украина. Тел.: + 38093-900-44-91, 8-(4563)-3-11-50. E-mail: stadnikap@ukr.net вес пашни, что вызвало интенсивные процессы ветровой и водной эрозии. В таких условиях существенно возрастает роль защитных лесных насаждений (ЗЛН) различного целевого назначения и их систем, как главного стабилизирующего фактора в агролесных экосистемах. В связи с этим, вопросы оптимизации систем ЗЛН как особо действенного средопреобразующего фактора являются особенно актуальными и требуют комплексной оценки в зональном разрезе, учитывая их целевое назначение, пространственную ориентацию, размещение, оптимальный состав с учетом типологических характеристик, конструктивные параметры и другие лесомелиоративные характеристики.

Цель исследований заключалась в разработке концептуальных основ создания оптимизированных систем защитных лесных насаждений в агроландшафтах, увеличении полезащитной лесистости сельскохозяйственных территорий и повышении экологической роли защитных лесных насаждений различного целевого назначения.

Анализ объемов создания полезащитных и защитных лесонасаждений в Украине свидетельствует о том, что площадь созданных полезащитных лесных полос с каждым годом уменьшается. Исследования проведенные в Бугско-Днепровском лесомелиоративном районе показали, что полезащитная лесистость региона составляет от 1,8\% - на территории Кировоградской обл. до 2,1-2,2\% - на территории Днепропетровской и Николаевской областей. Существующие показатели полезащитной лесистости в стране свидетельствуют о том, что они значительно ниже от установленных нормативов.

Оптимизированная система защитных лесных насаждений (ЗЛН) различного целевого назначения должна обеспечивать формирование устойчивого агролесного ландшафта, в котором стабилизируется экологическая ситуация, создаются оптимальные условия для развития, сохранности и продуктивности сельскохозяйственных культур. На плакоре и пахотных склонах создается система полезащитных, ветро- и стокорегулирующих лесных полос; гидрографическую сеть дополняет система прибрежных и прирусловых, балочных, ложбинных, пойменных і террасных ЗЛН. Создание полезащитных и стокорегулирующих лесных полос на водосборах является определяющим принципом для сбалансированного функционирования агроландшафтов.

Рассмотрены категории и системы ЗЛН в лесомелиоративных районах Украины, главные древесные породы для создания эффективных $3 Л Н$, особенности их роста в полезащитных лесных насаждениях различного породного состава. Обосновано пути создания оптимизированных систем $3 Л Н$, природоохранные и экологические приоритеты в агролесных экосистемах.

Разработан типологический подход для создания оптимизированных систем полезащитных лесных насаждений и рационального использования фиторазнообразия, рекомендовано ассортимент 
древесных и кустарниковых пород, а также типы лесных культур для различных лесорастительных условий.

Результаты исследований могут быть использованы для создания оптимизированных ЗЛН различного целевого назначения. Увеличение полезащитной лесистости даст возможность улучшить национальную экологическую сеть Украины, содействовать возобновлению природных экосистем и охраны агроландшафтов, успешному социальноэкономическому развитию страны. Кроме этого, уменьшатся угрозы деградации земель, создадутся благоприятные условия для ведения сельского хозяйства.

Ключевые слова: степная и лесостепная лесомелиоративные области; категории и системы; древесные породы; типы лесорастительных условий; ассортимент древесных растений.

\section{Optimization of the structure of protective forest plantations and their systems in agricultural landscapes of Ukraine}

\section{A. Stadnik ${ }^{1}$}

The intensification of agricultural production has significantly changed the structure of the land Fund, increased the ploughness and the proportion of arable land, causing intense processes of wind and water erosion. In such conditions, the role of protective forest plantations (PFP) of different purposes as the main stabilizing factor in agroforestry ecosystems is significantly increasing. In this regard, the issues of optimizing the systems of PFP as especially effective environment-transforming factor are particularly relevant and require a comprehensive assessment in the zonal context, taking into account their intended purpose, spatial orientation, location, optimal composition with consideration for typological characteristics, design parameters and other forest reclamation characteristics.

The purpose of the research was to develop the conceptual basis for the creation of optimized systems of protective forest plantations in agricultural landscapes,

\footnotetext{
Anatoliy Stadnik - full Member of the Forestry Academy of Sciences of Ukraine, Doctor of Agricultural Sciences, professor, senior research scientist, Head of the Department of Forestry, Botany and Phytophysiology. Belocerkovskiy national agrarian University, Soborna Square, 8/1, Bila Tserkva, 09117, Ukraine. Tel.: + 093-90044-91, 8-(4563)-3-11-50. E-mail: stadnikap@ukr.net
}

to increase the protective forest cover of agricultural areas and to enhance the ecological role of protective forest plantations for various target purposes.

The analysis of the volume of creation of fieldprotective stands (shelterbelts) and protective forest plantations in Ukraine shows that the area of the created shelterbelts decreases every year. The studies conducted in the Bug-Dnieper forest-land area showed that the forest shelterbelt percentage of the region varies from $1.8 \%$ - in Kirovograd region to $2.1-2.2 \%$ - on the territory of Dnipropetrovsk and Mykolaiv regions. The existing indexes of shelterbelt cover percentage in the country show that they are significantly lower than the established standards.

The optimized system of protective forest plantations (PFP) of various purposes should ensure the formation of a steady-state agroforestry landscape which stabilizes the environmental situation, creates optimal conditions for the development, preservation and productivity of agricultural crops. On upland soils and arable slopes, a system of shelterbelts, windbreaks, and flow-regulating forest belts is created; The hydrographic network is supplemented by a system of riparian and riverian, ravine, gorge, floodplain and terraced PFPs. Creation of shelterbelts and flow-regulating forest belts on catchments is a determining principle for the balanced functioning of agricultural landscapes.

Considered are: (1) categories and systems of PFP in forest-reclamation areas of Ukraine, (2) the main tree species for the creation of effective PFP, (3) peculiarities of their growth in the field-protective forest plantations of different species composition. The ways of creation of the optimized systems of PFP, nature-protection and ecological priorities in agroforestry ecosystems are substantiated.

A typological approach has been developed to create optimized systems of field-protective forest plantations and rational use of phytodiversity, a list of woody and shrub species, as well as types of forest cultures for various forest site conditions is recommended.

The results of the research can be used to create optimized PFP of different purposes. The increase of shelterbelt percentage will enable to improve the national ecological network of Ukraine, to promote the renewal of natural ecosystems and protection of agricultural landscapes, to foster the successful socioeconomic development of the country. In addition, the threat of land degradation will be reduced and favorable conditions for agriculture will be created.

Key words: steppe and forest-steppe forestreclamation areas; categories and systems; tree species; types of forest site conditions; list of woody plants. 